\title{
Determinants of Managerial Preventive Actions in Relation to Common Mental Disorders at Work
}

Citation for published version (APA):

van de Voort, I., de Rijk, A., Hensing, G., \& Bertilsson, M. (2019). Determinants of Managerial Preventive Actions in Relation to Common Mental Disorders at Work: A Cross-Sectional Study Among Swedish Managers. Journal of Occupational and Environmental Medicine, 61(10), 854-862.

https://doi.org/10.1097/JOM.0000000000001629

Document status and date:

Published: 01/10/2019

DOI:

10.1097/JOM.0000000000001629

Document Version:

Publisher's PDF, also known as Version of record

Document license:

Taverne

Please check the document version of this publication:

- A submitted manuscript is the version of the article upon submission and before peer-review. There can be important differences between the submitted version and the official published version of record.

People interested in the research are advised to contact the author for the final version of the publication, or visit the DOI to the publisher's website.

- The final author version and the galley proof are versions of the publication after peer review.

- The final published version features the final layout of the paper including the volume, issue and page numbers.

Link to publication

\footnotetext{
General rights rights.

- You may freely distribute the URL identifying the publication in the public portal. please follow below link for the End User Agreement:

www.umlib.nl/taverne-license

Take down policy

If you believe that this document breaches copyright please contact us at:

repository@maastrichtuniversity.nl

providing details and we will investigate your claim.
}

Copyright and moral rights for the publications made accessible in the public portal are retained by the authors and/or other copyright owners and it is a condition of accessing publications that users recognise and abide by the legal requirements associated with these

- Users may download and print one copy of any publication from the public portal for the purpose of private study or research.

- You may not further distribute the material or use it for any profit-making activity or commercial gain

If the publication is distributed under the terms of Article $25 \mathrm{fa}$ of the Dutch Copyright Act, indicated by the "Taverne" license above, 


\title{
Determinants of Managerial Preventive Actions in Relation to Common Mental Disorders at Work
}

\author{
A Cross-Sectional Study Among Swedish Managers
}

\author{
Iris van de Voort, MSc, Angelique de Rijk, PhD, Gunnel Hensing, PhD, and Monica Bertilsson, PhD
}

\begin{abstract}
Objective: Manager characteristics (personal, work-, and competencerelated) were investigated as determinants of managerial preventive actions (MPAs) in relation to common mental disorders (CMDs) among employees. Methods: A web survey $(n=2921)$ among Swedish managers measured diverse managerial characteristics and two types of MPAs: reviewing assignments and work situation (MPA-review); talking about CMDs at the work place (MPA-talk). Results: MPA-review was reported by $50 \%$ and MPA-talk by $57 \%$ of managers. Characteristics that related to more MPAs were female gender, workplace offering lectures on CMDs, workplace offering stress counseling, being responsible for the work environment, management training on CMDs, and more than 10 years of managerial experience (MPA-talk only). Conclusion: Managers who are female, have had training on CMDs, and work for organizations paying attention to CMD prevention initiate MPAs more often.
\end{abstract}

Keywords: anxiety, depression, managers, prevention

\section{PREVENTION OF COMMON MENTAL DISORDERS IN THE WORKING POPULATION}

C ommon mental disorders (CMDs) include depression, anxiety, and stress-related conditions. On average $20 \%$ of the workingage population in countries belonging to the Organisation for Economic Co-operation and Development develop one or more CMDs during working life. ${ }^{1}$ Many employees with CMDs continue working, but present with complaints (presenteeism), ${ }^{2}$ which puts employees at an increased risk for reduced work capacity and poor future general health. ${ }^{3,4}$ CMDs are indeed the most prevalent conditions in sick-listed employees in developed countries, and the leading cause for long-term sickness absence and disability. ${ }^{5}$ Return to work (RTW) takes longer among employees with CMDs than among employees with other disorders and adds to the importance of the matter. ${ }^{6}$ The elevated incidence and prevalence of CMDs among employees translates to an estimated total of 617 billion Euros every year for European countries and companies. ${ }^{7}$

Given the prevalence of CMDs among employees, the workplace may be an important venue for preventive intervention. ${ }^{8} \mathrm{Next}$ to a financial incentive to reduce costs associated with productivity loss, absenteeism, and compensation claims, employers in EU countries have a legal obligation to detect risk factors and

From the Department of Social Medicine, Care and Public Health Institute, Faculty of Health, Medicine and Life Sciences, Maastricht University, Maastricht, the Netherlands (Ms van de Voort, Dr de Rijk) and Institute of Medicine/Epidemiology and Social Medicine, The Sahlgrenska Academy, University of Gothenburg, Gothenburg, Sweden (Dr Hensing, Dr Bertilsson).

The project was granted by AFA Insurance, Sweden, Dnr:150378.

The authors have no conflicts of interest to declare.

Clinical significance: Managers take more actions to prevent common mental disorders among their subordinates if supported by in-company education for them and have counselling for their subordinates available.

Address correspondence to: Monica Bertilsson, PhD, Epidemiology and Social Medicine (EPSO), Department of Public Health and Community Medicine, P.O. Box 453, SE-405 30 Göteborg, Sweden (monica.bertilsson@gu.se).

Copyright (C) 2019 American College of Occupational and Environmental Medicine

DOI: $10.1097 / J O M .0000000000001629$ accordingly adopt preventive measures to protect the health of their workforce. ${ }^{9-11}$ Evidence suggests workplace interventions targeted at preventing CMDs to be effective. ${ }^{5,12}$ However, most interventions or guidelines focus on secondary and tertiary prevention aimed at detection of or avoiding further deterioration rather than on preventing its onset primarily. ${ }^{13,14}$ Although it is inherently harder to prevent the onset of CMDs, due its largely unknown, multifactorial, and multidirectional pathway that leads to its development, ${ }^{15}$ there is extensive evidence suggesting the specificity of certain risk factors in the work environment, such as job demands, job control, role stress, and workplace conflict. ${ }^{16}$ Many of these risk factors fall within the scope of managers' authority to be identified, controlled, adapted, reduced, or even eliminated. ${ }^{17}$ Yet, surprisingly, the managerial perspective in regards to the prevention of CMDs among employees is virtually absent in academic literature, particularly management literature. ${ }^{18}$

\section{MANAGERS' ROLE IN THE PREVENTION OF COMMON MENTAL DISORDERS}

Studies consistently show the significant effect of managers' behavior, support, or leadership-style on employee mental health. ${ }^{19,20}$ Managers are acknowledged to be key players in prevention, as they are conveniently situated between top management, the employee, coworkers, and (occupational) health care providers. ${ }^{21}$ Usually, managers operationalize, execute, or initiate employer's health and safety programs and plans. ${ }^{22}$ They often have the authority to modify work, adjust work conditions and environment, and are in one of the best positions to monitor (changes in) the health of employees. ${ }^{23}$ The majority of studies measure managerial behavior from the perspective of their subordinates or (senior) executives/employers. Indeed, with managers as the vehicle between employers and employees, it is important to measure whether and why actual managerial behaviors could deviate from the intention of employers, or be received/perceived differently by subordinates. Without measuring or including different perspectives, there would be superficial evaluation and only limited room to improve behaviors. Despite the added value of studying multiple perspectives, it remains surprising why only a few studies include the managers' own perspective. ${ }^{24}$

Given the presumed ways in which managers aid in the prevention of mental ill-health among their employees, it is insightful to expand perspectives others have of managers' roles with the perspective of managers themselves. By including the manager perspective, we gain a better understanding of their perceived ability, possibilities, and preparedness to contribute to the prevention of CMDs, but we will also reveal discrepancies between their perception and others' perception. All in all, these insights may reveal opportunities for intervention in order to improve the managers' role and capacity to prevent CMDs among employees.

\section{MANAGERIAL PREVENTIVE ACTIONS}

The few exceptions that take a managerial perspective in relation to the prevention of CMDs have focused on managers' attitudes (eg, stigma), ${ }^{25}$ their mental health literacy, ${ }^{26}$ or their 
experiences with the RTW process for employees with a mental disorder. $^{27,28}$ There is evidence though that managers' stress-preventive behaviors (as reported by themselves) have positive effects on employee affective well-being. ${ }^{29}$ The current study will focus on, what we named, managerial preventive actions (MPAs) in relation to CMDs among employees. Two MPAs will be distinguished. First, reviewing employee's assignments and work situation by the employer is required to decrease stress in the workplace in the EU. ${ }^{30}$ Second, talking about CMDs at the workplace can be supposed to lower the stigma, offering support and encouraging improvement of working conditions. ${ }^{8}$

\section{MANAGERS' CHARACTERISTICS AS DETERMINANTS OF MPAS}

This study focuses on determinants of these MPAs. On the basis of managerial literature, three types of determinants will be distinguished. First, it is argued that person-related characteristics of managers play a role as to whether managers initiate MPAs or not. Yet, in the management and leadership literature, there is inconclusive evidence on the effect of gender and level of education on displaying specific leadership styles and management behavior. ${ }^{31,32}$ Second, specific work-related characteristics of the environments in which managers work may influence if and to what extent they initiate MPAs. Theories of Organizational Behaviour argue for the inclusion of context in analyses of behavior within organization, as it may restrain or stimulate specific behaviors and hence account for variations in similar study populations. ${ }^{33,34}$ Third, competencerelated characteristics may explain why certain managers' initiate MPAs while others do not. Research shows that managers with more years of managerial work experience have more knowledge, expertise, and enhanced learning ability. ${ }^{35}$ It is possible that more experienced managers are more competent and confident in addressing mental health at the workplace, often perceived to be a difficult task. ${ }^{36}$ Other studies show that managers who have had training on the mental health of their employees have increased their mental health knowledge, confidence, and supportive behavior. ${ }^{37}$ It may have a similar effect on their preventive behavior.

In addition to person-related, work-related, and competencerelated characteristics, experience-related characteristics of managers may play a role in whether managers engage in preventive actions or not. First, having had personal experience with CMDs might make managers more inclined to initiate MPAs. ${ }^{38}$ Second, managers with previous occupational (mental) health care experience might have better understanding of the manifestation of CMDs, how it affects work capacity, and might acknowledge the relevance of prevention. ${ }^{39}$ Third, managers who have experienced employees with CMDs before could be more engaged in prevention, as demonstrated in case of other disabilities than CMDs. ${ }^{40}$

\section{AIM OF THE STUDY}

Recent studies recommend the need for more explicit research on the role of managers in the prevention of CMDs. ${ }^{41,42}$ In addition, more knowledge on the managerial perspective is important in order to improve managers' capacity to contribute to the prevention of CMDs among employees. This study aims to address the lack of a managerial perspective in a cross-sectional study testing the relationships pictured in Fig. 1.

The research questions are as follows:

(1) What is the frequency of MPA-review and MPA-talk among managers?

(2) To what extent are both MPAs determined by person-related, work-related, and competence-related characteristics of managers?

\section{METHODS}

\section{Study Design}

This study is part of the "Managers' perspective - the missing piece" project, which aims to study attitudes, knowledge, and needs among Swedish managers to support employees with depression and anxiety. Data on person-related, work-related, and competence-related characteristics, and MPAs among Swedish managers were collected in the autumn of 2017 through a webbased questionnaire. CMDs were formulated as depression and anxiety disorders throughout the questionnaire, as representing the two main categories of CMD diagnoses, and because they are more well-known than the concept CMD. ${ }^{42}$ The project received ethical approval from the Regional Ethical Review Board in Gothenburg, Sweden, Dnr: 165-17.

\section{Setting}

Employers in Sweden have to adhere to the Work Environment Act, a body of regulations obliging employers to take all necessary actions to prevent disease, accidents, and general ill health and hence ensure a healthy and safe work environment. ${ }^{43}$ The employer obligation extends to managers, supervisors, and employees. $^{44}$

\section{Participants}

Participants were recruited from the LORE Citizen Panel at the University of Gothenburg and the HELIX Competence Centre at Linköping University. The LORE Citizen Panel identified eligible members (ie, occupying a managerial position) by means of two questions included in the 26th Citizen Panel survey. ${ }^{45}$ Among those identified, 5000 managers were randomly invited to participate in the study by E-mail. The HELIX Competence Centre is a

FIGURE 1. Research model.

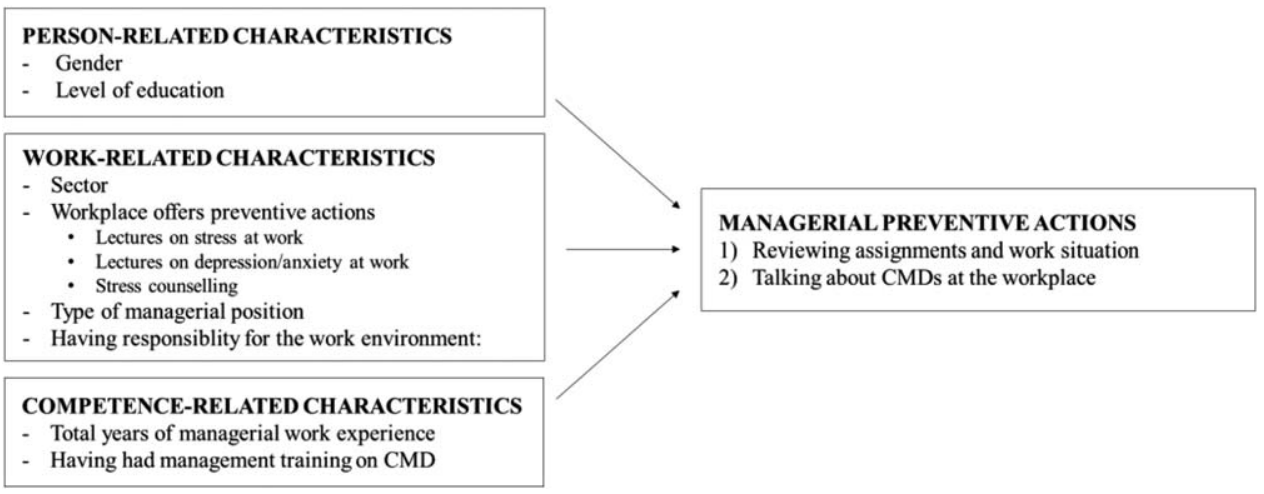


collaboration among 22 organizations (eg, universities, private, and public organizations) to promote the sustainable development of organizations. ${ }^{46}$ Eight organizations accepted participation and identified another 556 managers, who were similarly invited. Upon receiving the invitation, both groups received a short introduction on the aim of the study, were informed of the possibility to contact the responsible researcher, and were asked for consent to participate.

In total, the survey was sent to 5556 participants of whom 795 answered not occupying a managerial position (ie, wrongly identified as managers before sending the questionnaire) and 24 were excluded due to technical error, leaving 4737 as eligible participants, of whom $71 \%$ responded $(n=3358)$. In this study, participants were excluded when they reported to not have any direct staff responsibility (ie, managing " 0 " employees or not answering that particular question) $(n=437)$, leaving 2921 participants in the final study sample. For an overview, see Fig. 2.

\section{Measures}

\section{Managers' characteristics - independent variables}

- Person-related characteristics: "age" and "level of education" of the managers were included as person-related characteristics. The response options for gender included "women," "men," and "non-binary." Gender was dichotomized into "men" and "women," due to a low number of respondents indicating to be nonbinary $(n=3 ; 0,1 \%)$, yielding it unable to derive statistical inferences for this group. The response options for level of education were "compulsory school," "upper secondary school or equivalent," "degree from college/university (minimum three years)," and "other post-secondary education." For analyses, this was dichotomized into "secondary school or lower" and "post-secondary school."
- Work-related characteristics: "sector," "workplace offers preventive measures," "managerial position," and "having responsibility for the work environment" were included as work-related characteristics of the managers. First, response options for sector included "governmental," "municipal," and "county council/ regional," "private and non-profit organisation/foundation," which was dichotomized into "private" and "public \& nonprofit." Second, workplace offers preventive measures was measured as three items, each referring to a different preventive measure that had been offered to employees at the workplace, according to managers. These items were developed from workplace health promotion measures, investigated among employees. ${ }^{47}$ Managers were asked the following question: "Workplaces can engage in preventive measures to forestall the emergence of depression and/or anxiety disorders among staff members. Have staff members at your workplace been offered any of the following options during the past two years." Then, the three items/measures were presented, being (1) "lectures about stress at work," (2) "lectures about depression/anxiety at work," and (3) "stress counselling." Response options to each of these three actions were "Yes," "No," or "Don't know," which were later dichotomized into "Yes" and "No or don't know" for every item. Third, response options for type of managerial position were "senior manager," "middle manager" "first-line manager," "group leader/supervisor," and "expert/operations manager." These categories were dichotomized into "senior and operations managers" and "middle managers, first-line managers, and supervisors," based on the different nature of their core activities. Finally, response options to "having responsibility for the work environment" included "Yes," "No," or "Don't know," which was dichotomized into "Yes" and "No or Don't know."

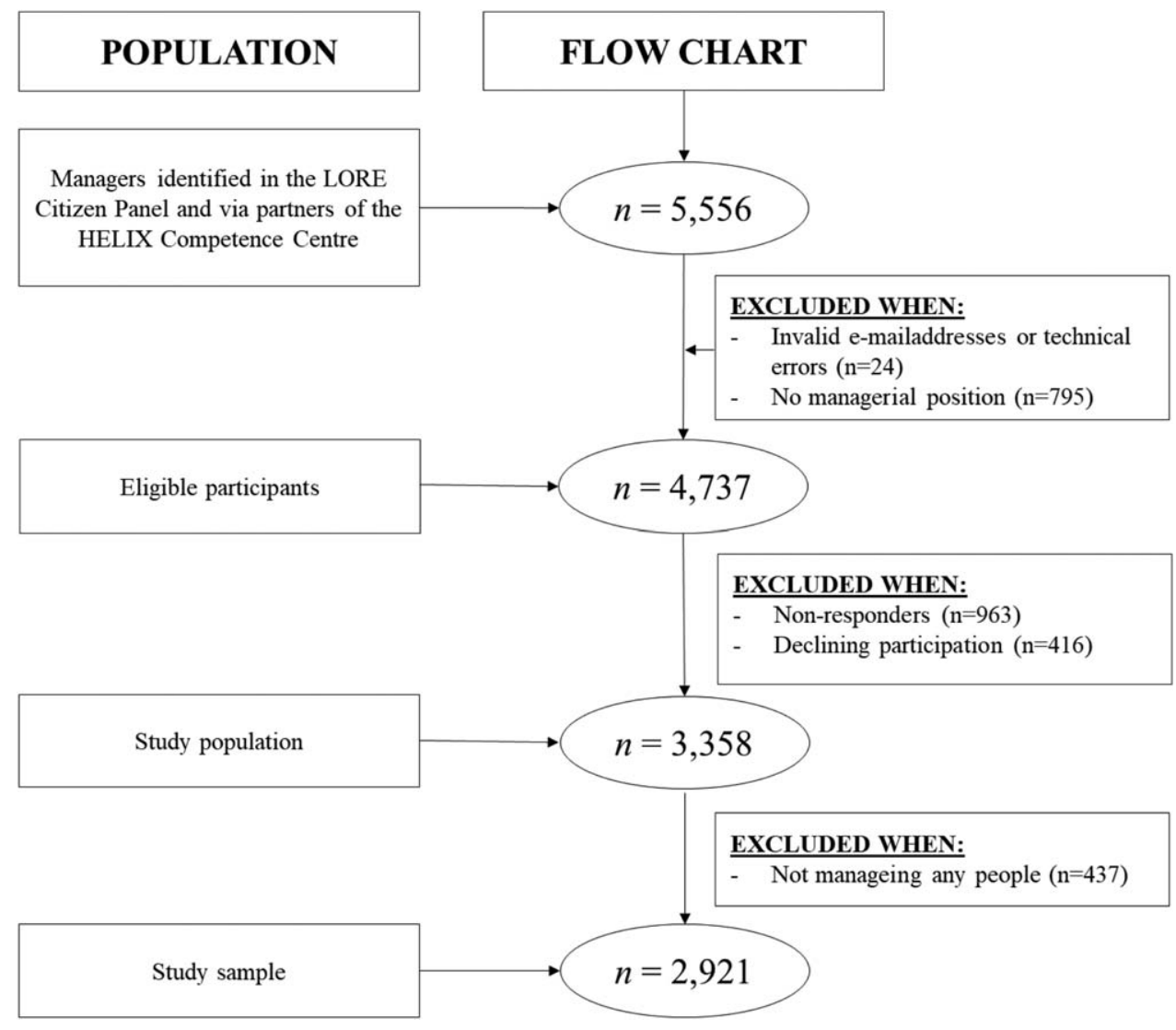

FIGURE 2. Flowchart from invited participants to study sample. 
- Competence-related characteristics: "total years of managerial work experience," and "having had management training on CMDs" were included within this category. Response options for total years of managerial work experience were "0-2 years," "3-5 years," "6-10 years," ">10 years." Following distribution along these categories, this variable was categorized into " $0-10$ years" or " $>10$ years." Response options to having had management training on CMDs included "Yes, during the last two years," "Yes, more than two years ago," and "No," which was dichotomized into "Yes" and "No."

\section{Managerial Preventive Actions (MPAs) - Dependent Variables}

- Reviewing assignments and work situation (MPA-review): The item measuring the first MPA was based on the Swedish Work Environment Act, that, parallel to other countries, address the issue of organizational and social work environment. ${ }^{44}$ Managers were asked the following question "During the past two years, have you reviewed the assignments and work situation of your staff members to forestall depression and anxiety among your staff"? Response options were "No, never," "Yes, 1-2 times," and "Yes, 3 or more times." This was dichotomized into "Yes" and "No, never."

- Talking about CMDs with employee (MPA-talk): This item was developed as a result of a survey among white-collar workers in Sweden, indicating that $60 \%$ never talked about mental health at any work place meetings (not published, http://www.nsph.se/ hjarnkoll). Managers were asked the following question: "During the past two years, have you in your capacity as manager/supervisor taken any initiative to talk about depression or anxiety with the aim of increasing understanding of mental illness at your workplace"? Response options included "No, never," "Yes, in individual performance appraisals," "Yes, occasionally in the working group," and "Yes, on several occasions in the working group." Multiple answers were possible (eg, in the individual settings and in the working group). A new variable was computed to distinguish between those managers who had taken the initiative to talk about CMDs in at least one setting (or more) versus those who had never done so.

\section{Covariates}

Managers might have acquired experience that could influence their ability and inclination to initiate MPAs. In addition, the number of employees in organizations is included as a covariate to adjust for the likelihood that workplace health and prevention measures are usually more common in larger ( $>250$ employees) organizations. 48

- Having had experience with CMDs, either personally or through a close friend or relative: Managers were asked the following question: "Have you personally, or has a close relative or a friend, had depression and/or anxiety disorder?" Response options included "Yes" or "No."

- Having been in occupations treating or caring for people with CMDs: Respondents were asked the following question: "During your professional life, have you worked in occupations where you cared for or treated people with depression and/or anxiety disorders?" Response options included "Yes" or "No."

- Having had employees with CMDs before: Managers were asked the following question: "During the past two years, have you had staff members at your current workplace who have had depression and/or anxiety disorders?" Response options were "Yes, several staff members," "Yes, one staff member," "No, no staff member," and "Don't know," which was dichotomized into "Yes" and "No/Don't know" for analyses.

- Number of employees in organization: "How many staff members are in your company/organisation in total?" Response options included "0-9," "10-49," “50-250," "251-1,000," and "more than 1,000." This was dichotomized into " $0-250$ " to reflect micro, small, and medium-sized organizations and " $>250 "$ " to reflect larger organizations. ${ }^{49}$

\section{Statistical Methods}

All analyses were performed with IBM SPSS Statistics 22 (IBM Corp., Armonk, NY). In regards to the first research question, frequencies, expressed in count and percentage, were explored for initiated MPAs, as well as person-related, work-related, and competence-related characteristics and covariates. To answer the second research question, binary logistic regression analyses were conducted to measure associations between the independent variables on the one hand, and the MPAs on the other hand. Before performing logistic regression, multi-collinearity between the independent variables was checked and no significant strong correlations were found. Thereafter, logistic regression analyses were conducted for both MPAs separately to generate odds ratios (ORs) with a 95\% confidence interval (95\% CI) between independent variables and the MPAs. Next to bivariate analyses between one determinant and an MPA, multivariate analyses were conducted to reflect a more realistic representation of the presence of multiple determinants and their interaction on each other in order to understand the effect of determinants on an MPA. All in all, regression was conducted in three subsequent ways: first, through bivariate analyses (Model 1) and second, through multivariate analyses for each category of characteristics separately (Model 2 to 4). In these models, the covariates were also included. Finally, all independent variables were entered simultaneously in multivariate analyses (Model 5), including the covariates. Missing values were reported for every variable in descriptive analyses and a sample size per analysis, excluding missing values, was reported for each regression analysis separately.

\section{RESULTS}

\section{Descriptive Analyses}

Descriptives are presented in Table 1. With regard to the frequency of initiated MPAs, managers indicate that they review assignments and work situation (MPA-review) in 50\% of the cases and they talk about CMDs at the work place (MPA-talk) (in at least one setting) in $57 \%$ of the cases.

\section{Determinants of MPA-review}

Results of bivariate and multivariate binary logistic regression are presented in Table 2. First, separate bivariate analyses yielded significant associations between a characteristic and initiating MPA-review, with the exception of total years of managerial experience (Model 1). Second, separate multivariate analyses for each of the three categories of characteristics were conducted, while simultaneously adjusting for the covariates (model 2 to 4). Person-related characteristics, when entered together, remained significant, although the odds slightly attenuated. The odds between work-related characteristics and initiating MPA-review also lowered, and "managerial position" and "lectures about stress at work" as a workplace preventive measure became insignificant. The odds between competence-related characteristics and initiating MPA-review changed only marginally, and total years of managerial work experience remained insignificant. Finally, all characteristics were included simultaneously regardless of the category to which they belonged and in addition adjusted for covariates (Model 5). Female managers have a 1.42 (95\% CI 1.17 to 1.73 ) times higher odds than male managers to initiate MPA-review. Managers in workplaces where lectures on CMDs or stress counseling are offered as preventive measures, respectively, have a 1.36 (95\% CI 1.01 to 1.83$)$ and 1.79 (95\% CI 1.46 to 2.20$)$ 
TABLE 1. Descriptives of Study Sample $(n=2,921)$

\begin{tabular}{|c|c|c|}
\hline & $N$ & $\%$ \\
\hline \multicolumn{3}{|l|}{ Person-related characteristics } \\
\hline \multicolumn{3}{|l|}{ Gender } \\
\hline Men & 1,971 & 68 \\
\hline Women & 938 & 32 \\
\hline Nonbinary & 3 & 0 \\
\hline Missing values & 9 & 0 \\
\hline \multicolumn{3}{|l|}{ Level of education } \\
\hline Secondary school or lower & 454 & 16 \\
\hline Post-secondary school & 2,441 & 84 \\
\hline Missing values & 26 & 1 \\
\hline \multicolumn{3}{|l|}{ Work-related characteristics } \\
\hline \multicolumn{3}{|l|}{ Sector } \\
\hline Private & 1,715 & 59 \\
\hline Public or nonprofit & 1,203 & 41 \\
\hline Missing values & 3 & 0 \\
\hline \multicolumn{3}{|l|}{ Workplace offers preventive measures } \\
\hline \multicolumn{3}{|l|}{ Lectures about stress at work } \\
\hline Yes & 1,076 & 37 \\
\hline No/do not know & 1,487 & 51 \\
\hline Missing values & 358 & 12 \\
\hline \multicolumn{3}{|l|}{ Lectures about depression and anxiety at work } \\
\hline Yes & 345 & 12 \\
\hline No/do not know & 2,214 & 76 \\
\hline Missing values & 362 & 12 \\
\hline \multicolumn{3}{|l|}{ Stress counseling } \\
\hline Yes & 1,090 & 37 \\
\hline No/do not know & 1,461 & 50 \\
\hline Missing values & 370 & 13 \\
\hline \multicolumn{3}{|l|}{ Type of managerial position } \\
\hline Senior or operations managers & 853 & 29 \\
\hline Middle managers, line-managers, and supervisors & 1,991 & 68 \\
\hline Missing values & 77 & 3 \\
\hline Responsibility for the work environment & & \\
\hline Yes & 2,127 & 73 \\
\hline No/do not know & 744 & 26 \\
\hline Missing values & 50 & 2 \\
\hline Competence-related characteristics & & \\
\hline Total years of managerial work experience & & \\
\hline $0-10$ years & 1,415 & 48 \\
\hline$>10$ years & 1,467 & 50 \\
\hline Missing values & 39 & 1 \\
\hline Having had management training on CMDs & & \\
\hline Yes & 718 & 25 \\
\hline No & 1,892 & 65 \\
\hline Missing values & 311 & 10 \\
\hline Managerial preventive actions (MPAs) & & \\
\hline MPA-review: Reviewing assignments and work situa & & \\
\hline Yes & 1,450 & 50 \\
\hline No, never & 1,113 & 38 \\
\hline Missing values & 358 & 12 \\
\hline MPA-talk: Talking about CMDs with at the workpla & & \\
\hline Yes in at least one setting & 1,653 & 57 \\
\hline Only in individual performance appraisals & 951 & 33 \\
\hline Only in the working group & 494 & 17 \\
\hline In both settings & 208 & 7 \\
\hline No, never & 922 & 32 \\
\hline Missing values & 346 & 12 \\
\hline Covariates & & \\
\hline $\begin{array}{l}\text { Having had experience with CMDs, either personally } \\
\text { relative }\end{array}$ & gh a clo & \\
\hline Yes & 1,998 & 68 \\
\hline No & 616 & 21 \\
\hline Missing values & 307 & 11 \\
\hline Having been in occupations treating or caring for pe & CMDs & \\
\hline Yes & 413 & 14 \\
\hline No & 2,198 & 75 \\
\hline Missing values & 310 & 11 \\
\hline Having supervised employees with CMDs before: & & \\
\hline Yes & 1,684 & 58 \\
\hline No/Do not know & 928 & 32 \\
\hline Missing values & 309 & 11 \\
\hline Number of employees in organization & & \\
\hline $0-250$ & 1,474 & 51 \\
\hline$>250$ & 1,443 & 49 \\
\hline Missing values & 4 & 0 \\
\hline
\end{tabular}

Italic sections stands for the descriptives how MPA-talk was originally measured, being 4 options rather than 2 . times higher odds to initiate MPA-review than managers whose workplaces do not offer these preventive measures. When managers have responsibility for the work environment, they also show a 1.42 (95\% CI 1.15 to 1.74$)$ times higher odds to initiate MPA-review than managers without this responsibility. Finally, managers having had management training on CMD have a 1.56 (95\% CI 1.27 to 1.93$)$ times higher odds to initiate MPAreview than managers untrained in CMDs. Other characteristics became insignificant when considered together and adjusted for covariates.

\section{Determinants of MPA-talk}

Results of bivariate and multivariate binary logistic regression are presented in Table 3. First, separate bivariate analyses yielded significant associations between a characteristic and initiating MPA-talk, with the exception of managerial position (Model 1). Second, separate multivariate analyses for each of the three categories of characteristics were conducted, while simultaneously adjusting for the covariates (model 2 to 4). Within person-related characteristics, level of education became insignificant when considered simultaneously with gender and the covariates, while gender remained significant, but the odds to initiate MPA-talk became lower. The odds between work-related characteristics and initiating MPA-talk also attenuated, and only "having responsibility for the work environment" and "lectures on depression/ anxiety" and "stress counselling" as workplace preventive measures remained significant. The odds between competence-related characteristics and initiating MPA-talk changed only marginally and remained significant when considered together including the covariates. Finally, all characteristics were included simultaneously regardless of the category to which they belonged and in addition adjusted for covariates (Model 5). Female managers have 1.33 (95\% CI 1.08 to 1.64) higher odds than male managers to initiate MPA-talk. Managers in workplaces who offer lectures on CMDs or stress counseling as preventive measures, respectively, have 1.84 (95\% CI 1.30 to 2.60) and 1.53 (95\% CI 1.22 to 1.91 ) higher odds to initiate MPA-talk. When managers have responsibility for the work environment, they also show a 1.44 (95\% CI 1.16 to 1.79 ) higher odds to initiate MPA-talk. Managers who have more than 10 years of managerial work experience show a 1.23 (95\% CI 1.01 to 1.50 ) higher odds to initiate MPA-talk. Finally, managers having had management training on CMD show 1.61 (95\% CI 1.28 to 2.03) higher odds to initiate MPA-talk. Other characteristics became insignificant when considered together and adjusted for covariates.

\section{DISCUSSION}

This cross-sectional study conducted among 2921 Swedish managers explored the frequency of two types of MPAs among managers and the association with three categories of managers' characteristics. We found that $50 \%$ of managers reported to review assignments and work situation (MPA-review) and 57\% of managers talked about CMDs at the workplace (MPA-talk) with the intention to prevent CMDs among employees. Moreover, every category of characteristics included one or more determinants of MPAs, expressing the contextual and multidimensional background of these managerial behaviours. ${ }^{25,34}$ These were reported irrespective of the manager's level of education, sector, or type of managerial position. Strong statistical effects of gender were found though. Female managers in this study consistently reported to initiate more MPAs than male managers, which is line with other research that found female managers to pertain more importance and confidence to address mental health of employees. ${ }^{50}$

Further, managers reported MPAs most when they perceive to be working in organizations that provided specific lectures on depression and anxiety and stress counseling. These findings on 
TABLE 2. Crude and Adjusted Odds Ratios (OR) with 95\% Confidence Interval (Cl) for "Reviewing Assignments and Work Situation (MPA-review)" in Respect to Independent Variables

\begin{tabular}{|c|c|c|c|c|c|c|}
\hline \multirow[b]{2}{*}{ Independent Variables } & \multicolumn{6}{|c|}{ MPA-review: Reviewing Assignments and Work Situation } \\
\hline & $n$ & $\begin{array}{l}\text { Model 1: } \\
\text { Crude OR } \\
(95 \% \text { CI })\end{array}$ & $\begin{array}{l}\text { Model 2: } \\
\text { OR }(95 \% \text { CI }) \\
n=2,525\end{array}$ & $\begin{array}{c}\text { Model 3: } \\
\text { OR }(95 \% \text { CI }) \\
n=2,434\end{array}$ & $\begin{array}{l}\text { Model 4: } \\
\text { OR }(95 \% \mathrm{CI}) \\
n=\mathbf{2 , 5 2 0}\end{array}$ & $\begin{array}{l}\text { Model 5: } \\
\text { OR }(95 \% \text { CI }) \\
n=2,392\end{array}$ \\
\hline \multicolumn{7}{|l|}{ Person-related characteristics } \\
\hline Gender (women) & 2,554 & $1.67(1.41-1.99)$ & $1.41(1.18-1.68)$ & & & $1.42(1.17-1.73)$ \\
\hline Level of education (post-secondary) & 2,544 & $1.53(1.24-1.90)$ & $1.34(1.07-1.68)$ & & & $1.15(0.90-1.47)$ \\
\hline \multicolumn{7}{|l|}{ Work-related characteristics } \\
\hline Sector (public or nonprofit) & 2,561 & $1.73(1.48-2.04)$ & & $1.27(1.05-1.53)$ & & $1.16(0.96-1.42)$ \\
\hline $\begin{array}{c}\text { Workplace offers preventive measure } \\
\text { (lectures about stress at work, yes) }\end{array}$ & 2,544 & $1.82(1.55-2.14)$ & & $1.08(0.87-1.33)$ & & $1.03(0.83-1.27)$ \\
\hline $\begin{array}{l}\text { Workplace offers preventive measure } \\
\text { (lectures about depression/anxiety } \\
\text { at work, yes) }\end{array}$ & 2,540 & $2.26(1.75-2.91)$ & & $1.48(1.11-1.98)$ & & $1.36(1.01-1.83)$ \\
\hline $\begin{array}{l}\text { Workplace offers preventive measure } \\
\text { (stress counseling, yes) }\end{array}$ & 2,532 & $2.50(2.12-2.95)$ & & $1.87(1.53-2.28)$ & & $1.79(1.46-2.20)$ \\
\hline $\begin{array}{l}\text { Type of managerial position (middle, } \\
\text { line, supervisor) }\end{array}$ & 2,502 & $1.20(1.01-1.43)$ & & $1.06(0.87-1.31)$ & & $1.02(0.83-1.26)$ \\
\hline $\begin{array}{l}\text { Having responsibility for the work } \\
\text { environment (yes) }\end{array}$ & 2,537 & $1.77(1.48-2.12)$ & & $1.49(1.22-1.82)$ & & $1.42(1.15-1.74)$ \\
\hline \multicolumn{7}{|l|}{ Competence-related characteristics } \\
\hline $\begin{array}{l}\text { Total years of managerial work } \\
\text { experience }(>10 \text { years })\end{array}$ & 2,534 & $1.00(0.85-1.17)$ & & & $0.95(0.81-1.13)$ & $0.90(0.75-1.08)$ \\
\hline Having had management training on CMDs (yes) & 2,559 & $1.85(1.54-2.22)$ & & & $1.83(1.51-2.22)$ & $1.56(1.27-1.93)$ \\
\hline
\end{tabular}

Model 1: bivariate analyses.

Model 2: multivariate analyses for person-related characteristics entered together, adjusted for having had personal experience with CMDs (or through a friend or relative), having had occupational experience treating or caring for individuals with CMDs, having had staff members with CMDs before, and number of employees in organization.

Model 3: multivariate analyses for work-related characteristics entered together, adjusted for having had personal experience with CMDs (or through a friend or relative), having had occupational experience treating or caring for individuals with CMDs, having had staff members with CMDs before, and number of employees in organization.

Model 4: multivariate analyses for competence-related characteristics entered together, adjusted for having had personal experience with CMDs (or through a friend or relative), having had occupational experience treating or caring for individuals with CMDs, having had staff members with CMDs before, and number of employees in organization. Model 5: full model, all characteristics entered together and adjusted for having had personal experience with CMDs (or through a friend or relative), having had occupational experience treating or caring for individuals with CMDs, having had staff members with CMDs before, and number of employees in organization. Bold stands for significant results in the final model.

TABLE 3. Crude and Adjusted Odds Ratios (OR) with 95\% Confidence Interval (Cl) for "talking about CMDs at the workplace (MPA-talk)" in Respect to Independent Variables

\begin{tabular}{|c|c|c|c|c|c|c|}
\hline \multirow[b]{2}{*}{ Independent Variables } & \multicolumn{6}{|c|}{ MPA-talk: Talking About CMDs at the Workplace } \\
\hline & $n$ & $\begin{array}{l}\text { Model 1: } \\
\text { Crude OR } \\
(95 \% \text { CI })\end{array}$ & $\begin{array}{c}\text { Model 2: } \\
\text { OR }(95 \% \text { CI }) \\
n=2,534\end{array}$ & $\begin{array}{c}\text { Model 3: } \\
\text { OR }(95 \% \text { CI }) \\
n=2,444\end{array}$ & $\begin{array}{c}\text { Model 4: } \\
\text { OR }(95 \% \text { CI }) \\
n=2,531\end{array}$ & $\begin{array}{c}\text { Model 5: } \\
\text { OR }(95 \% \text { CI }) \\
n=2,402\end{array}$ \\
\hline \multicolumn{7}{|l|}{ Person-related characteristics } \\
\hline Gender (women) & 2,566 & $1.67(1.40-2.00)$ & $1.30(1.07-1.58)$ & & & $1.33(1.08-1.64)$ \\
\hline Level of education (post-secondary) & 2,555 & $1.42(1.14-1.76)$ & $1.23(0.97-1.56)$ & & & $1.14(0.88-1.48)$ \\
\hline \multicolumn{7}{|l|}{ Work-related characteristics } \\
\hline Sector (public or nonprofit) & 2,573 & $1.66(1.40-1.96)$ & & $1.18(0.97-1.45)$ & & $1.12(0.90-1.38)$ \\
\hline $\begin{array}{c}\text { Workplace offers preventive measure } \\
\text { (lectures about stress at work, yes) }\end{array}$ & 2,554 & $1.84(1.56-2.18)$ & & $1.07(0.85-1.34)$ & & $1.01(0.80-1.28)$ \\
\hline $\begin{array}{l}\text { Workplace offers preventive measure } \\
\text { (lectures about depression/anxiety at work, yes) }\end{array}$ & 2,550 & $2.92(2.19-3.91)$ & & $1.99(1.42-2.79)$ & & $1.84(1.30-2.60)$ \\
\hline $\begin{array}{l}\text { Workplace offers preventive measure } \\
\text { (stress counseling, yes) }\end{array}$ & 2,543 & $2.43(2.05-2.89)$ & & $1.62(1.30-1.98)$ & & $1.53(1.22-1.91)$ \\
\hline Type of managerial position (middle, line, supervisor) & 2,515 & $1.02(0.86-1.22)$ & & $0.81(0.65-1.02)$ & & $0.83(0.66-1.05)$ \\
\hline Having responsibility for the work environment (yes) & 2,550 & $1.96(1.63-2.35)$ & & $1.60(1.30-1.98)$ & & $1.44(1.16-1.79)$ \\
\hline \multicolumn{7}{|l|}{ Competence-related characteristics } \\
\hline Total years of managerial work experience $(>10$ years $)$ & 2,547 & $1.29(1.10-1.52)$ & & & $1.29(1.08-1.55)$ & $1.23(1.01-1.50)$ \\
\hline Having had management training on CMD (yes) & 2,571 & $2.15(1.77-2.62)$ & & & $2.06(1.66-2.55)$ & $1.61(1.28-2.03)$ \\
\hline \multicolumn{7}{|l|}{ Model 1: bivariate analyses. } \\
\hline $\begin{array}{l}\text { Model 2: multivariate analyses for person-related charact } \\
\text { had occupational experience treating or caring for individu } \\
\text { Model 3: multivariate analyses for work-related characte } \\
\text { had occupational experience treating or caring for individu } \\
\text { Model 4: multivariate analyses for competence-related cl } \\
\text { having had occupational experience treating or caring for } \\
\text { Model 5: full model, all characteristics entered together } \\
\text { experience treating or caring for individuals with CMDs, h }\end{array}$ & $\begin{array}{l}\text { stics ent } \\
\text { with C } \\
\text { ics ente } \\
\text { with C } \\
\text { acterist } \\
\text { viduals } \\
\text { d adjust } \\
\text { ng had }\end{array}$ & $\begin{array}{l}\text { d together, adjustec } \\
\text { s, having had staf } \\
\text { together, adjusted } \\
\text { s, having had staf } \\
\text { entered together, ac } \\
\text { th CMDs, having } \\
\text { for having had per } \\
\text { ff members with }\end{array}$ & $\begin{array}{l}\mathrm{r} \text { having had pers } \\
\text { hembers with } \mathrm{CM} \\
\text { having had perso } \\
\text { lembers with } \mathrm{CM} \\
\text { ted for having ha } \\
\text { staff members } \\
\text { al experience wit } \\
\text { Ds before, and }\end{array}$ & $\begin{array}{l}\text { experience with } \mathrm{CI} \\
\text { before, and numbe } \\
\text { experience with } \mathrm{CN} \\
\text { before, and numbe } \\
\text { ersonal experience } \\
\text { CMDs before, and } \\
\text { MDs (or through a }\end{array}$ & $\begin{array}{l}\mathrm{s} \text { (or through a frier } \\
\mathrm{f} \text { employees in ors } \\
\text { (or through a frier } \\
\mathrm{f} \text { employees in ors } \\
\text { CMDs (or throug } \\
\text { mber of employee } \\
\text { nd or relative), hav }\end{array}$ & $\begin{array}{l}\text { r relative), having } \\
\text { zation. } \\
\text { r relative), having } \\
\text { zation. } \\
\text { friend or relative), } \\
\text { organization. } \\
\text { had occupational }\end{array}$ \\
\hline
\end{tabular}


workplace preventive measures are in line with literature that advocates a cross-level effect of organizational measures taken at a higher level on individual behavior at a lower level. ${ }^{33}$ Elsewhere, managers have voiced that a supportive work environment that makes the topic of mental (ill-) health more salient through awareness campaigns, company policies, and education assists them in addressing mental illness at work as well. ${ }^{51}$ Lectures on stress were not significantly associated with initiating either MPA. This might have a methodological explanation (see below), express a lack of knowledge on the relationship between stress and depression/anxiety, or suggest that lectures need to be tailored in order to link knowledge and behavior.

In line with the findings regarding lectures that were offered to all employees and that might have contributed to a positive, more open organizational climate for talking about CMDs, managers were also more likely to report MPAs if they had received explicit management training on CMDs. A recent meta-analysis confirms a positive effect of interventions on managers' understanding of mental health, understanding of their role and responsibility, attitudes and behavior addressing employees' mental health needs. ${ }^{52}$ In addition to an overall positive climate regarding CMDs, knowledge and skills to handle CMDs seem thus important to take actions to prevent CMDs. Finally, being formally responsible for the work environment also seemed to promote MPAs. Thus, formal organizational policies and directives add to the positive climate and competence building regarding MPAs.

\section{Strengths and Limitations}

Regarding the representativeness and generalizability of the sample, an important strength is the inclusion of managers from different sectors and managerial levels. This is certainly a major improvement compared with other studies. ${ }^{53}$ The sample represents the Swedish managers well in relation to gender (sample/Sweden: 32/39\% women, 68/61\% men), but the study sample included a larger proportion of managers from the public sector (sample/Sweden: $41 / 21 \%$ public sector; $59 / 79 \%$ private sector). ${ }^{54}$ However, the sample might have been biased toward managers who have had personal experience with CMDs. In this sample, $71 \%$ of managers indicated personal experience of CMDs. This has been acknowledged by being corrected for in the models, and the associations between the determinants and MPAs hardly changed.

The findings represent the distinct context that typifies Swedish organizations with generally lower levels of hierarchy ${ }^{55}$ and a higher level of gender equality (see: http://hdr.undp.org/en/ data\#). Lower burnout levels have been observed in countries with less hierarchic environments, higher gender equality, and less masculine cultures, and the same may be the case for other CMDs. ${ }^{56}$ Perhaps lower levels of hierarchy encourages more discourse on sensitive topics such as mental health between managers and employees. In addition, studies show that stereotypical traits and behavior of women and men are likely to transcend to the worksetting, with female managers being considered more "communal," or expressing more concern for the wellbeing of others than male managers. ${ }^{57}$ Females in Sweden are considered more equal than other countries, and hence may feel less pressure to conform to more masculine leadership styles or experience more freedom to address the wellbeing of employees.

Despite the large group of participants, the study sample was a lot smaller due to high attrition as a result of the web-survey method. Using the AAPOR Standard definitions $2011^{58}$ for respondents, three levels of participation were identified among the total respondents $(n=3358)$, responses which is those answering $80 \%$ or more of the study questions $(n=2821)$, partials answering between $50 \%$ and $79 \%$ of the questions $(n=278)$, and break-offs answering less than $49 \%$ of the questions $(n=259)$. The items on MPAs were positioned at the end of the survey, therefore subject to relatively more attrition, although some partials and break-offs did respond to the MPA questions and skipped questions before in the survey.

Another important limitation though is that this study did not address the possible outcomes of MPAs. It might be that MPAs prevent CMDs through their effect on certain work-related stressors such as a role stress or lack of support, but this need to be studied. Neither can it be assumed that MPAs specifically prevent the onset of CMDs (ie, primary prevention). It might potentially also contribute to the prevention of deterioration of already developed CMDs (ie, secondary prevention) or facilitate rehabilitation and RTW of employees with CMDs (ie, tertiary prevention). Further, given the cross-sectional design, apart from women and more than 10 years of managerial work experience, the associations found between the managers' characteristics and initiated MPAs pertain to a specific point in time and hence no conclusion can be drawn in regards to the direction of the association.

Another limitation was that the two MPAs were measured with only one item each, which reduces reliability and thus validity. The chance for social desirable answers might have been increased, for example, among managers who are aware of the legal obligation of employers and managers to protect the health of employees who might have felt pressure to confirm that they performed MPAs. Also, the two MPA items included the terms "depression" and "anxiety," which might have led to common method variance with the independent variable on lectures about depression and anxiety. This methodological factor might also explain the lack of association with lectures on stress.

\section{Future Research}

This study clearly contributed to filling the knowledge gap on managers' preventive actions regarding their subordinates' CMDs. Future research should have longitudinal design. Research may be directed at identifying other MPAs in relation to the prevention of CMDs. Further, a multilevel design, including outcomes at subordinate level (eg, mental health complaints, CMDs, sickness absence, and presenteeism due to CMDs) is recommended. Also, other determinants could be included. For instance, both Pomaki et $\mathrm{al}^{59}$ and Pransky et al ${ }^{60}$ highlight the importance of investigating workplace mental health stigma. The measures for MPAs could be improved by adding items and improving the reliability of the measures. Also, future research could investigate which types of training have a positive effect on MPAs, or how to promote male managers to enact MPAs more. Finally, cross-country comparison studies should reveal the extent to which gender equality and low hierarchy in workplaces are related to MPAs.

\section{Implications for Practice}

In line with the research findings, employers and occupational health services could consider to adopt organizational policies, preventive measures, and management training in order to stimulate managers' ability and inclination to initiate actions to improve their subordinates' mental health.

\section{CONCLUSION}

This study addressed a contemporary knowledge gap in the field of work-related mental health research by exploring the managers' perspective in the prevention of CMDs among employees. We found that managers' initiation of MPAs is multidimensionally determined by person-, competence-, but particularly workrelated characteristics. Regardless, these first findings indicate that managers could be more inclined to initiate MPAs when supported by in-company management education and a supportive work environment, where preventive measures such as lectures on CMDs and stress counseling are provided company-wide. Future research 
is encouraged to include and elaborate on the managers' perspective in CMD prevention.

\section{REFERENCES}

1. Organisation for Economic Co-operation and Development. Sick on the Job? Myths and Realities About Mental Health and Work. Paris: OECD Publishing; 2012.

2. Sanderson K, Andrews G. Common mental disorders in the workforce: recent findings from descriptive and social epidemiology. Can J Psychiatry. 2006;51:63-75.

3. Danielsson L, Bertilsson M, Holmgren K, Hensing G. Working in dissonance: experiences of work instability in workers with common mental disorders. BMC public health. 2017;17:472-482.

4. Bergström G, Bodin L, Hagberg J, Lindh T, Aronsson G, Josephson M. Does sickness presenteeism have an impact on future general health? Int Arch Occup Environ Health. 2009;82:1179-1190.

5. Tan L, Wang M-J, Modini M, et al. Preventing the development of depression at work: a systematic review and meta-analysis of universal interventions in the workplace. BMC Med. 2014;12:74-84.

6. Hensing G, Bertilsson M, Ahlborg G, Waern M, Vaez M. Self-assessed mental health problems and work capacity as determinants of return to work: a prospective general population-based study of individuals with all-cause sickness absence. BMC Psychiatry. 2013;13:259-270.

7. Cosemans B, Cosmar M, Gründler R, Flemming D, Van den Broek K. Calculating the Cost of Work-related Stress and Psychosocial Risks: a Literature Review. Luxembourg: European Agency for Safety and Health at Work; 2014

8. Organisation for Economic Co-operation and Development. Fit Mind, Fit Job: From Evidence to Practice in Mental Health and Work. Paris: OECD Publishing; 2015.

9. Ford MT, Cerasoli CP, Higgins JA, Decesare AL. Relationships between psychological, physical, and behavioural health and work performance: a review and meta-analysis. Work Stress. 2011;25:185-204.

10. Goetzel RZ, Long SR, Ozminkowski RJ, Hawkins K, Wang S, Lynch W Health, absence, disability, and presenteeism cost estimates of certain physical and mental health conditions affecting US employers. J Occup Environ Med. 2004;46:398-412.

11. Goetzel RZ, Ozminkowski RJ, Sederer LI, Mark TL. The business case for quality mental health services: why employers should care about the mental health and well-being of their employees. J Occup Environ Med. 2002;44:320-330.

12. Carolan S, Harris PR, Cavanagh K. Improving employee well-being and effectiveness: systematic review and meta-analysis of web-based psychological interventions delivered in the workplace. $J$ Med Internet Res. 2017; $19:$ e271.

13. Bertilsson M, Bejerholm U, Ståhl C. Preventive measures to prevent and reduce sickness absence due to common mental disorders: a literature review of Swedish research and changes in Swedish legislation. Soc Med Tidskr. 2017;94:531-545.

14. Memish K, Martin A, Bartlett L, Dawkins S, Sanderson K. Workplace mental health: an international review of guidelines. Prev Med. 2017;101:213-222.

15. Cuijpers P, Van Straten A, Smit F. Preventing the incidence of new cases of mental disorders: a meta-analytic review. J Nerv Ment Dis. 2005;193:119_ 125.

16. Harvey SB, Modini M, Joyce S, et al. Can work make you mentally ill? A systematic meta-review of work-related risk factors for common mental health problems. Occup Environ Med. 2017;74:301-310.

17. Attridge M, Wallace S. Able-minded: Return to Work and Accommodations for Workers on Disability Leave for Mental Disorders. Vancouver: Human Solutions; 2010.

18. De Lorenzo MS. Employee mental illness: moving towards a dominant discourse in management and HRM. Int J Bus Manag. 2014;9:133-144.

19. Theorell T, Hammarström A, Aronsson G, et al. A systematic review including meta-analysis of work environment and depressive symptoms. BMC public health. 2015;15:738-751.

20. Montano D, Reeske A, Franke F, Hüffmeier J. Leadership, followers' mental health and job performance in organizations: a comprehensive meta-analysis from an occupational health perspective. J Organ Behav. 2017;38:327-350.

21. Johnston V, Way K, Long MH, Wyatt M, Gibson L, Shaw WS. Supervisor competencies for supporting return to work: a mixed-methods study. J Occup Rehabil. 2015;25:3-17.

22. Sparrow P, Cooper CL. A Research Agenda for Human Resource Management. Cheltenham: Edward Elgar Publishing Limited; 2017.
23. Ellis AM, Casey TW, Krauss AD. Setting the foundation for well-being: evaluation of a supervisor-focused mental health training. Occ Health Sc. 2017;1:67-88.

24. Little K, Henderson C, Brohan E, Thornicroft G. Employers' attitudes to people with mental health problems in the workplace in Britain: changes between 2006 and 2009. Epidemiol Psychiatr Sci. 2011;20:73-81.

25. Martin A. Individual and contextual correlates of managers' attitudes toward depressed employees. Hum Resour Manage. 2010;49:647-668.

26. Hauck K, Chard G. How do employees and managers perceive depression: a worksite case study. Work. 2009;33:13-22.

27. Lemieux P, Durand M-J, Hong QN. Supervisors' perception of the factors influencing the return to work of workers with common mental disorders. J Occup Rehabil. 2011;21:293-303.

28. Holmgren K, Ivanoff SD. Supervisors' views on employer responsibility in the return to work process. A focus group study. J Occup Rehabil. 2007; 17:93-106.

29. Toderi S, Balducci C. Stress-preventive management competencies, psychosocial work environments, and affective well-being: a multilevel, multisource investigation. Int J Environ Res Public Health. 2018;15:397-412.

30. European Council Directive. The Introduction of Measures to Encourage Improvements in the Safety and Health of Workers at Work 89/391/EEC. European Union; 1989.

31. Belias D, Gkolia A, Koustelios A, Varsanis K. Leadership style and personal characteristics of Greek banking employees. J Manage Res. 2015;15:156164.

32. Burke S, Collins KM. Gender differences in leadership styles and management skills. Wom Manage Rev. 2001;16:244-257.

33. Johns G. The essential impact of context on organizational behavior. Acad Manag Rev. 2006;31:386-408.

34. Martin A, Karanika-Murray M, Biron C, Sanderson K. The psychosocial work environment, employee mental health and organizational interventions: improving research and practice by taking a multilevel approach. Stress Health. 2016;32:201-215.

35. Jiang F, Ananthram S, Li J. Global mindset and entry mode decisions: moderating roles of managers' decision-making style and managerial experience. Manag Int Rev. 2018;58:413-447.

36. Kirsh B, Krupa T, Luong D. How do supervisors perceive and manage employee mental health issues in their workplaces? Work. 2018;59: 547-555.

37. Milligan-Saville JS, Tan L, Gayed A, et al. Workplace mental health training for managers and its effect on sick leave in employees: a cluster randomised controlled trial. Lancet Psychiatry. 2017;4:850-858.

38. Dawkins S, Martin A, Kilpatrick M, Scott J. Reasons for engagement: SME owner-manager motivations for engaging in a workplace mental health and wellbeing intervention. J Occup Environ Med. 2018;60:917-927.

39. Bertilsson M, Löve J, Ahlborg Jr G, Hensing G. Health care professionals' experience-based understanding of individuals' capacity to work while depressed and anxious. Scand J Occup Ther. 2015;22:126-136.

40. Gates LB, Akabas SH, Kantrowitz W. Supervisor's role in successful job maintenance: a target for rehabilitation counselor efforts. J Appl Rehabil Counsel. 1996;27:60-66.

41. Martin A, Woods M, Dawkins S. Managing employees with mental health issues: identification of conceptual and procedural knowledge for development within management education curricula. Acad Manag Learn Edu. 2015; $14: 50-68$.

42. World Health Organization. Depression and Other Common Mental Disorders: Global Health Estimates. Geneva: WHO Document Production Services; 2017

43. The Swedish Work Environment Authority. Work Environment Act (1977:1160), Amendments: up to and Including SFS 2014:659. Stockholm: The Swedish Work Environment Authority; 2014.

44. The Swedish Work Environment Authority. Organisational and Social Work Environment. The Swedish Work Environment Authority Provisions on Organisational and Social Work Environment, with General Recommendations on Applications Thereof. Stockholm: The Swedish Work Environment Authority; 2015.

45. Martinsson J, Andreasson M, Lindgren E. Technical report Citizen Panel 262017. Gothenburg: University of Gothenburg, LORE; 2017.

46. HELIX Competence Centre. (Information on the program) n.d. Available at: https://liu.se/en/research/helix-competence-centre. Accessed May 18, 2018.

47. Larsson R, Ljungblad C, Sandmark H, Åkerlind I. Workplace health promotion and employee health in Swedish municipal social care organizations. J Public Health. 2014;22:235-244. 
48. Taylor A, Pilkington R, Montgomerie A, Feist H. The role of business size in assessing the uptake of health promoting workplace initiatives in Australia. BMC Public Health. 2016;16:353-360.

49. European Commission. User Guide to the SME Definition. Luxembourg: Publications Office of the European Union; 2015.

50. Shann C, Martin A, Chester A. Improving workplace mental health: a training needs analysis to inform beyond blue's online resource for leaders. Asia Pac J Hum Res. 2014;52:298-315.

51. Dewa CS, Burke A, Hardaker D, Caveen M, Baynton MA. Mental health training programs for managers: what do managers find valuable? Can $J$ Commun Ment Health. 2007;25:221-239.

52. Gayed A, Milligan-Saville JS, Nicholas J, et al. Effectiveness of training workplace managers to understand and support the mental health needs of employees: a systematic review and meta-analysis. Occup Environ Med. 2018;75:462-470.

53. Carlson MD, Morrison RS. Study design, precision, and validity in observational studies. J Palliat Med. 2009;12:77-82.
54. Statistics Sweden. Women and Men in Enterprice 2013. Örebro: Statistics Sweden; 2013

55. Gibson C. An investigation of gender differences in leadership across four countries. J Int Bus Stud. 1995;26:255-279.

56. Schaufeli, W. Burnout in Europe: relations with national economy, governance and culture. Research Unit Occupational \& Organizational Psychology and Professional Learning (internal report). Belgium: KU Leuven; 2018.

57. Heilman M. Description and prescription: how gender stereotypes prevent women's ascent up the organizational ladder. J Soc Issues. 2001;57:657-674.

58. The American Association for Public Opinion Research. Standard Definitions: Final Dispositions of Case Codes and Outcome Rates for Surveys: AAPOR; 2011.

59. Pomaki G, Franche R-L, Khushrushahi N, Murray E, Lampinen T, Mah P. Best Practices for Return-to-work/Stay-at-work Interventions for Workers with Mental Health Conditions. Vancouver: Occupational Health and Safety Agency for Healthcare in BC (OHSAH); 2010.

60. Pransky GS, Fassier J-B, Besen E, et al. Sustaining work participation across the life course. J Occup Rehabil. 2016;26:465-479. 